\title{
Ukrainian scientific journals in the branches of juridical, economic, humanitarian and social sciences: a systematization
}

\author{
Vasylkiv Yu., Mys O., Boyko V. and Vlokh R. \\ Vlokh Institute of Physical Optics, 23 Dragomanov Street, 79005, Lviv, Ukraine, \\ vlokh@ifo.lviv.ua
}

Received: 22.02 .2018

\begin{abstract}
We analyze the state of affairs with the Ukrainian journals and proceedings specialized in the fields of humanitarian, social, economic and juridical sciences. According to a number of criteria suggested by us, all of the available 1214 Ukrainian editions are divided into seven categories. We have found that the highest category A is empty, 5 editions belong to the category B, 5 to the category C, 23 to the category D, 24 to the category E, and 1034 to the category F. Finally, the lowest category, G, includes 123 issues. Following from the results obtained, one can see that only editions belonging to the categories B-E satisfy $81 \%$ of the necessary criteria. The total scores for these journals and proceedings are equal or higher than 15 .
\end{abstract}

Keywords: specialized journals, humanitarian sciences, social sciences, economic sciences, juridical sciences

PACS: $01.30 . \mathrm{Tt}$

UDC: 001.002

\section{Introduction}

The aim of this work is to continue our recent studies of the situation with specialized scientific Ukrainian journals and proceedings [Vasylkiv Yu. et al., 2017. Ukr. J. Phys. Opt. 18: 28-45]. In the present study we review the Ukrainian specialized scientific journals and proceedings concerned with the fields of humanitarian, social, economic and juridical sciences.

A general approach employed for ranking the specialized scientific journals and proceedings has been described in our recent work. Below we remind the main principles of this ranking in brief. Our system of journal evaluation is based on the known criteria that precede appointing of scientometric indices to journals, basing on their citation analysis. As a consequence, the journals covered by Web of Science or Scopus and, in particular, those having prescribed scientometric indices, have to hold the highest positions in the journal ranking and form the category A. Besides, the process of admission of a journal to the covering mentioned above is based on the following criteria: timeliness of publication; adhering to common international editorial conventions; publishing of full texts of articles (or, at least, bibliographical data and abstract) in English; application of peer-reviewing procedures; enriching of content of scientometric databases (or some specific topic of the latter) with a journal under evaluation; international diversity among contributing authors, journal's editors and Editorial Advisory Board members; importance of regional scholarship, etc.

All of these criteria have been involved when evaluating the Ukrainian specialized journals and proceedings [Vasylkiv Yu. et al., 2017. Ukr. J. Phys. Opt. 18: 28-45]. As a result, we have used the following specific criteria (or 'conditions') for our editions evaluation: (1) availability of digital object identifier (DOI) for the articles published in a isuue, (2) coverage by Web of 
Science, (3) coverage by Scopus, (4) coverage by the national database "Ukrainika Scientific" or the database "Index Copernicus", (5) timeliness of publication of a journal, (6) availability of website with full texts of articles in Ukrainian, (7) availability of web-site with English abstracts, and (8) availability of web-site with full texts of articles in English.

In principle, a fact of meeting each of these criteria might have been evaluated quantitatively by adding a single point to the total journal's score. However, it is obvious that different criteria are of different importance. This is accounted for via introducing relevant weighing coefficients. For example, availability of DOI for the articles published in a certain edition and inclusion of the latter to Web of Science or Scopus databases have the same weighing coefficient, 25. The weighting coefficients referred to the remaining criteria (4), (5), (6), (7) and (8) are equal to 2, 7, 3, 3 and 10 points, respectively. If a edition satisfies all of the criteria mentioned above, it is characterized by the total score 100 . Any journal possessing an impact factor surely satisfies these criteria. Thus, its score can be determined as $100+10 I F$, where $I F$ denotes the impact factor.

Basing on the ranking of editions carried out as described above, we have plotted the distribution of journals and proceedings scores versus the quantity of editions with a certain score. Then the cumulative Pareto distribution function can be used:

$$
F(x)=\left\{\begin{array}{l}
1-\left(\frac{x_{m}}{x}\right)^{\alpha} \text { if } x \geq x_{m}, \\
0 \text { if } x<x_{m}
\end{array},\right.
$$

where $F(x)$ is the relative quantity of editions which make the relative cumulative score contribution $x$ to the total score, $x_{m}$ the minimal relative cumulative contribution to the total score, and $\alpha$ the Pareto exponent. On the basis of this distribution the Pareto ratio $n_{1} /\left(100-n_{1}\right)$ can be determined. It is given by the percentage $n_{1}$ of editions which satisfy $100-n_{1}$ per cents of our criteria concerned with entry of these editions into International databases and their scientometric indices.

As mentioned above, we have earlier analyzed all the Ukrainian editions referred to any of scientific fields such as the natural sciences, engineering, veterinary and the agriculture [Vasylkiv Yu. et al., 2017. Ukr. J. Phys. Opt. 18: 28-45]. A separate analysis of the journals and proceedings specialized in the veterinary, agriculture, physics and mathematics, biology, chemistry, geography and geology has also been performed. The list of journals and proceedings, publications in which are taken into account when awarding the Degrees of Candidate (Philosophy Doctor) or Doctor of Sciences, has been approved by the Decrees of the Ministry of Education and Science of Ukraine $[1,2]$. We have divided all of the Ukrainian journals and proceedings referred to the natural sciences into seven categories, A-G. In particular, the category A contains the journals with prescribed impact factors. The category B contains the journals which have prescribed scientometric indices assigned by the Scopus database but still do not have an impact factor. We have also taken into account the scientometric indices SNIP and SCImago Journal Rank (SJR) (see Ref. [3]) for this category. The journals included to Web of Science (Emerging Sources Citation Index) or Scopus belong to the category $\mathrm{C}$ only if their scientometric indices have not yet been calculated. The category D embraces the journals and proceedings which are not covered by Web of Science and Scopus and have no scientometric indices, under the condition that the articles published in these editions have DOI assigned. The next category, E, includes the journals and proceedings that satisfy the minimal requirements laid to scientific journals. They must meet at least the criteria (4)-(7) and so earn the scores higher than 15 . The editions with the total score 15 or lower are 
included to the category F. Finally, the journals and proceedings with a zero total score or those which have not been published during the last two years belong to the lowest category, G.

\section{Results and discussion}

The list of journals and proceedings specializing in the branches of humanitarian, social, economic and juridical sciences contain 1214 items in the total (see Refs. [1, 2]). None of these editions has a prescribed impact factor, so that the category A is empty at this time. In particular, the impact factor has not been prescribed for the humanitarian journals in principle. As seen from Table 1, the category B contains only 5 journals. All of them are included to Web of Science. Table 2 testifies that 5 editions can be referred to the category C. Then, 23 editions belong to the category D (see Table 3). The category E consists of 24 editions. Note that meeting the criteria (4)-(8) seems to be a minimal necessary condition for any scientific journal. The minimal score for these periodicals is equal to 25. The corresponding editions are as follows:

1. Economic Processes Management;

2. Bulletin Taras Shevchenko National University of Kyiv. Ukrainian Studies;

3. Derzhavne Upravlinnya: Udoskonalennya ta Rozvytok;

4. Uzhgorod National University Herald. Series: International Economic Relations and World Economy;

5. Scientific Journal of Kherson State University. Series: Economic Sciences;

6. Osvitolohiya.

1034 editions with the total scores lower than 15 are referred to the category F. Finally, 123 journals and proceedings belong to the lowest category, G. It is almost obvious that these editions have long ceased to exist. In fact, they must not have been taken into account in any serious scientometric analysis.

The histograms of distributions of the scores for the Ukrainian editions obtained with different bin sizes are shown in Fig. 1. As seen from Fig. 1b, more than 1000 items have the scores equal or lower than 15 . Usually these editions satisfy the following conditions: (i) they are covered by the databases "Ukrainika Scientific" or "Index Copernicus", (ii) they are published in time, (iii) Ukrainian full texts are available on their web-sites, and (iv) English abstracts of articles are available on their web-sites. However, full versions of articles in these editions cannot be evaluated by the international scientific community, since only English is a commonly accepted language of science. Moreover, the above journals and proceedings are not present in the largest
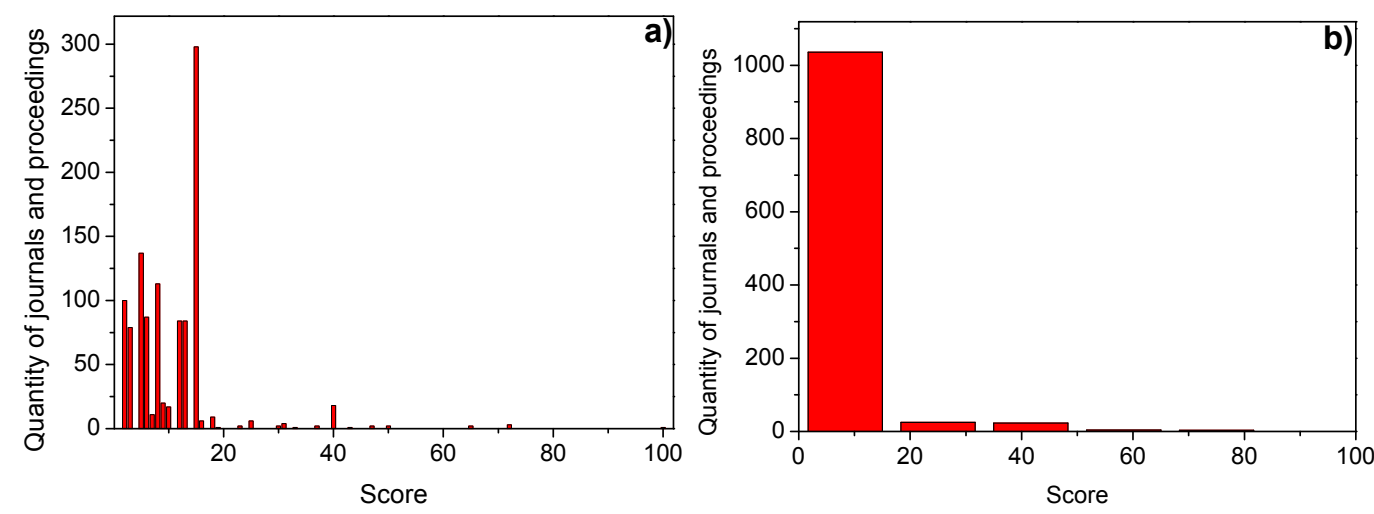

Fig. 1. Histograms of Pareto distribution for the scores of Ukrainian journals and proceedings specialized in the fields of humanitarian, social, juridical and economical sciences: (a) bin size equal to 1; (b) bin size equal to 15 . 


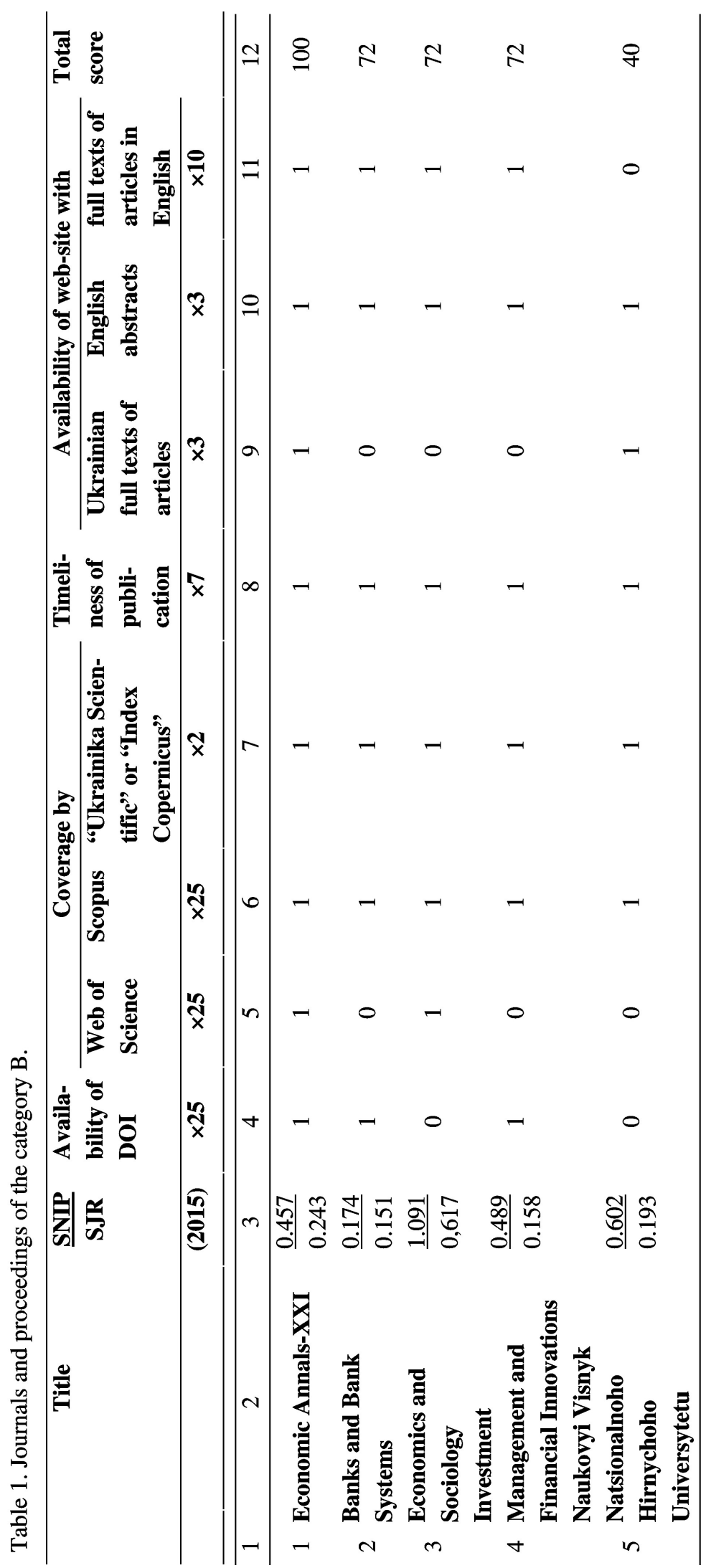

Ukr. J. Phys. Opt. 2018, Volume 19, Issue 2 


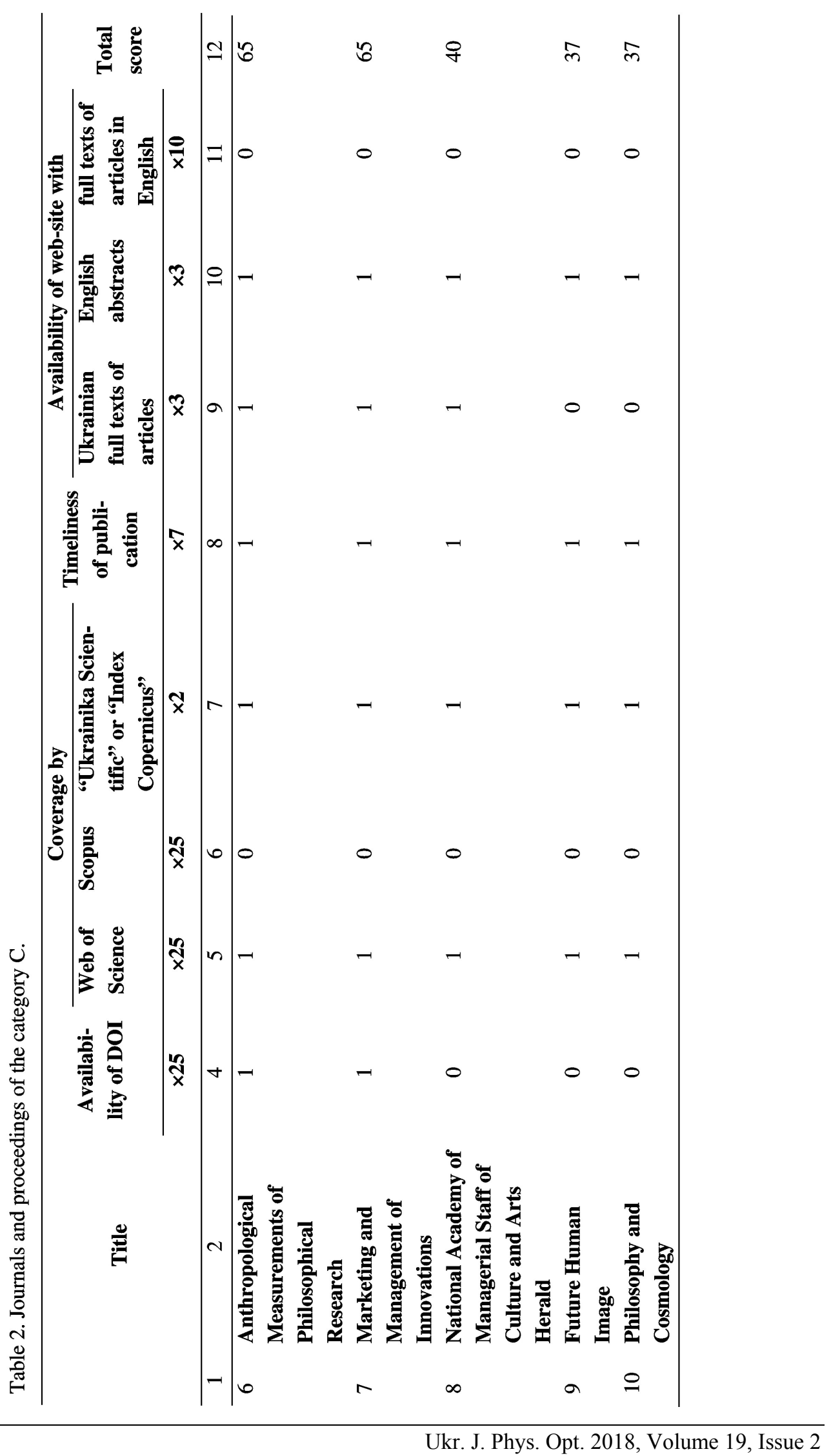




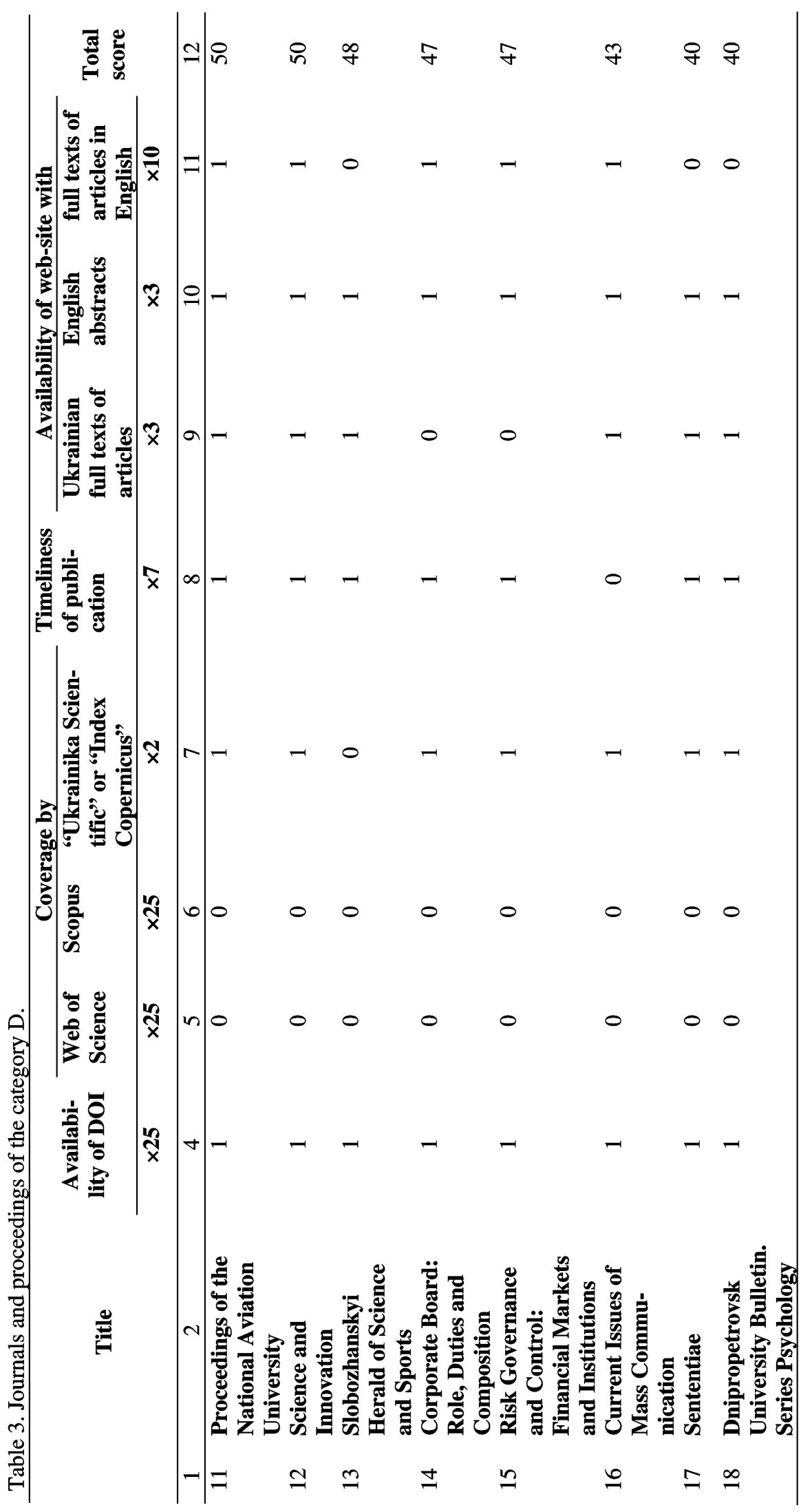

Ukr. J. Phys. Opt. 2018, Volume 19, Issue 2 


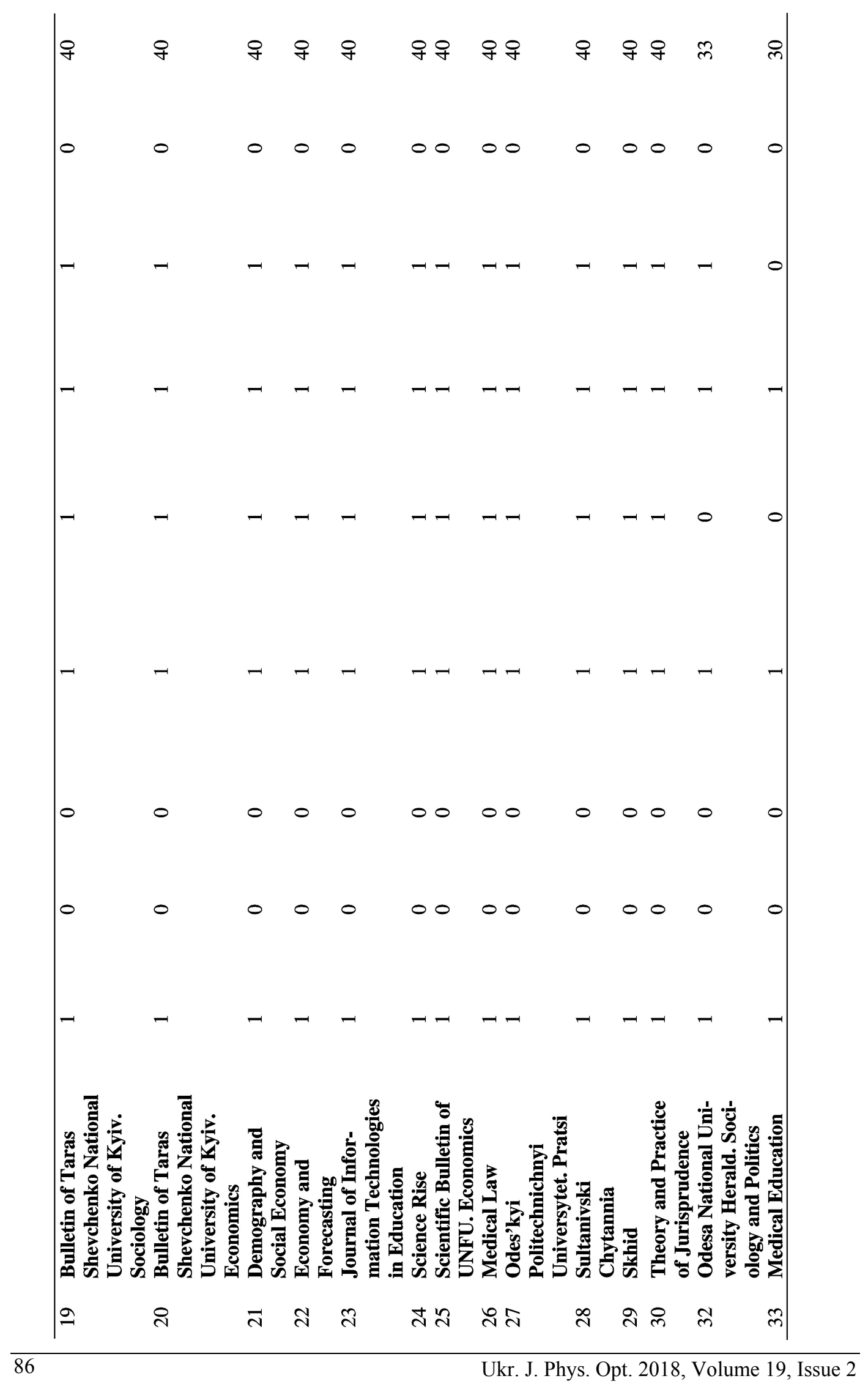


International databases. In addition, the articles published in these editions have no DOI assigned, thus making them invisible in specialized Internet space. Hence, the Ukrainian editions suitable for publishing scientific works accounted for $\mathrm{PhD}$ thesis defence should have the minimal score higher than 15 .

Let us consider the cumulative Pareto distribution for all the Ukrainian journals and proceedings under study, except for the items of the category G (see Fig. 2a). One can see from Fig. 2a that the corresponding Pareto ratio is equal to $81 / 19$. In other words, $19 \%$ of the journals and proceedings satisfy $81 \%$ of the necessary criteria of the editions formulated in Section 1 . These $19 \%$ of the items must have corresponded to 208 journals and proceedings with the highest scores. However, the total number of the appropriate editions belonging to the categories $\mathrm{B}-\mathrm{E}$ is only 57, which is seen from Tables 1-3. The difference can be related to high relative errors of the Pareto fitting, which reaches $15 \%$. The rest of the items, the total number of which is equal to 1034 (i.e., $81 \%$ of all editions included to the category F), satisfy only $19 \%$ of the necessary criteria. By the highest standards, they have not to be taken into account in the official governmental attestation of specialists in Ukraine. The same concerns the official evaluation of scientific projects in Ukraine, which is based on the articles published by the projects' authors.
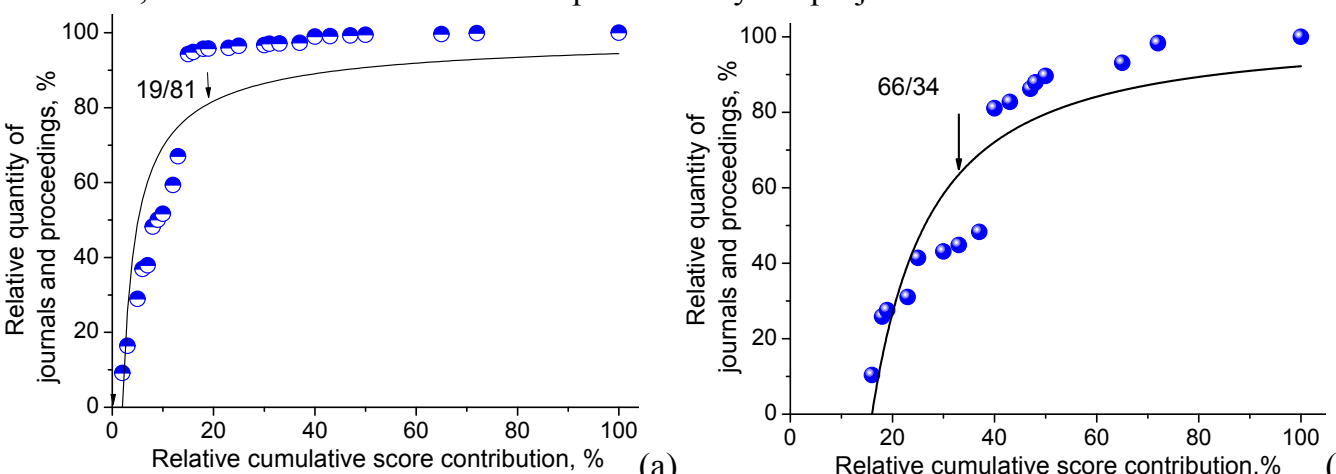

Fig. 2. Cumulative Pareto distributions for ranking the Ukrainian journals and proceedings specialized in the fields of humanitarian, social, juridical and economical sciences: (a) set of 1091 periodicals and (b) set of 57 editions with the highest scores .

As seen from Fig. 2b, the Pareto ratio for the best 57 journals is equal to $66 / 34$. This means that $34 \%$ of these editions (i.e., about 20 periodicals with the highest scores) meet additional $66 \%$ of criteria out of $19 \%$ of the criteria, which have not been satisfied for the rest of the editions (see Fig. 2a). As a consequence, $\sim 20$ journals and proceedings satisfy $88 \%$ of all the necessary conditions. With accounting for the fitting errors, one can refer to this group the editions belonging to the categories B and, partly, C and D. These are the items with the total scores 40 or higher (see Tables 1-3). The conditions necessary for reaching such the scores are meeting of at least one of the three following demands: (i) availability of DOI for articles published in a journal and proceedings; (ii) coverage of this journal by Web of Science; or (iii) its coverage by Scopus.

We consider now the cumulative Pareto distributions for the journals and proceedings referred to humanitarian sciences as a whole (see Fig. 3a), and separately to culturology (Fig. 3b), philosophy (Fig. 3c), philology (Fig. 3d) and arts sciences (Fig. 3e). The Pareto ratio for the editions corresponding to all the humanitarian sciences is equal to $76 / 24$, while the total number of journals and proceedings that correspond to the mentioned branches of sciences is equal to 303 . Thus, $24 \%$ of items satisfy $76 \%$ of all the criteria. In fact, with accounting for the fitting error $(\sim 10 \%)$, one can refer 13 items to these $24 \%$ of the editions. Their scores are higher than 15 . 

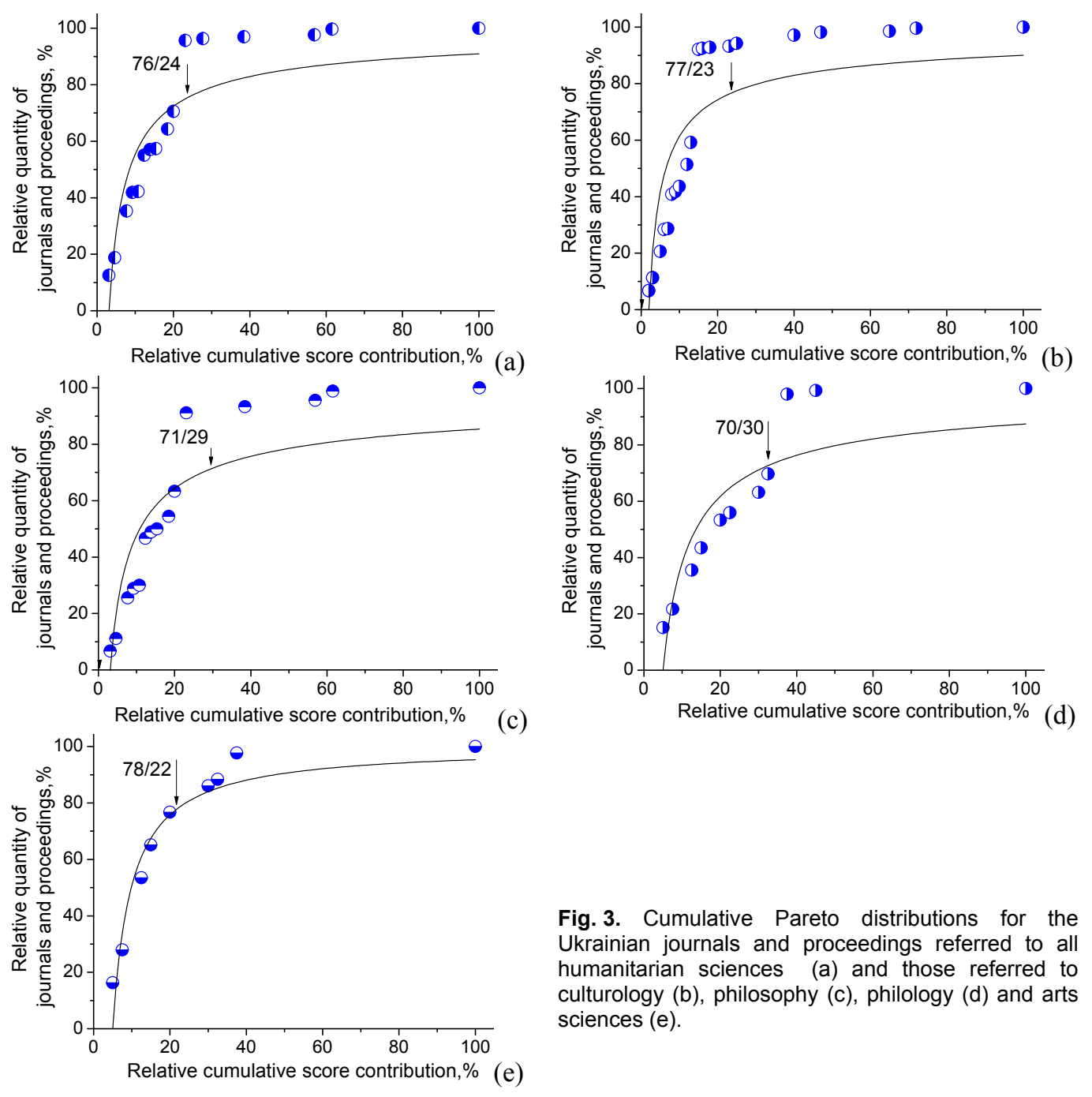

Fig. 3. Cumulative Pareto distributions for the Ukrainian journals and proceedings referred to all humanitarian sciences (a) and those referred to culturology (b), philosophy (c), philology (d) and arts sciences (e).

Let us proceed to the separate statistics for the journals and proceedings referred to each of the humanitarian scientific fields. Only one among 18 journals and proceedings related to culturology has the score higher than 15 (see Fig. 3b). This is "National Academy of Managerial Staff of Culture and Arts Herald", with the score 40 . The editions of this group satisfy $77 \%$ of the necessary conditions, with the relative error of fitting equal to $17 \%$. For the journals and proceedings specialized in philosophy, the Pareto ratio is equal to 71/29 (see Fig. 3c). The total number of editions in this scientific field is $89.29 \%$ of these journals and proceedings amount to 7 items. They have the total scores higher than 15 . The relative fitting error in this case is equal to $21 \%$. As seen from Fig. 3d, the Pareto ratio is equal to $70 / 30$ for the editions referred to philology. The total number of items in this scientific field is equal to 152 . Hence, $30 \%$ of them correspond to 3 items, with the fitting error $28 \%$. As usual, the minimal score of these items is higher than 15 . At the same time, only one edition has the score equal or higher than 25. This is "Sultanivski Chytannia", with the score 40. Notice that, according to the results of our recent study [Vasylkiv Yu. et al., 2017. Ukr. J. Phys. Opt. 18: 28-45], this is the minimal score for the journals specialized in the fields of natural sciences, engineering, medicine, veterinary and agriculture. Finally, the Pareto ratio for the journals and proceedings specialized in the arts science is equal to 78/22 (see Fig. 4e). 
Ukrainian scientific
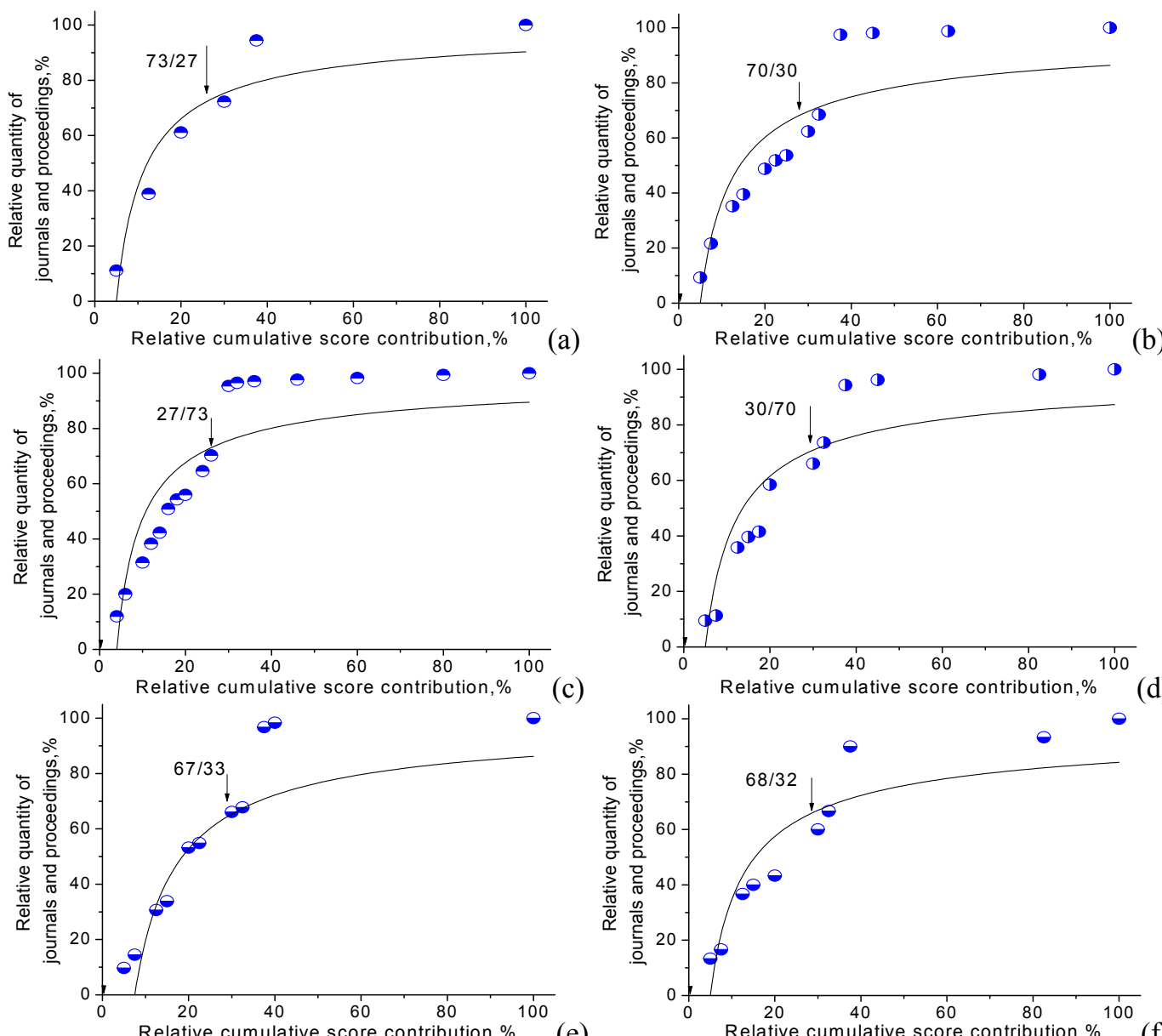

(c)
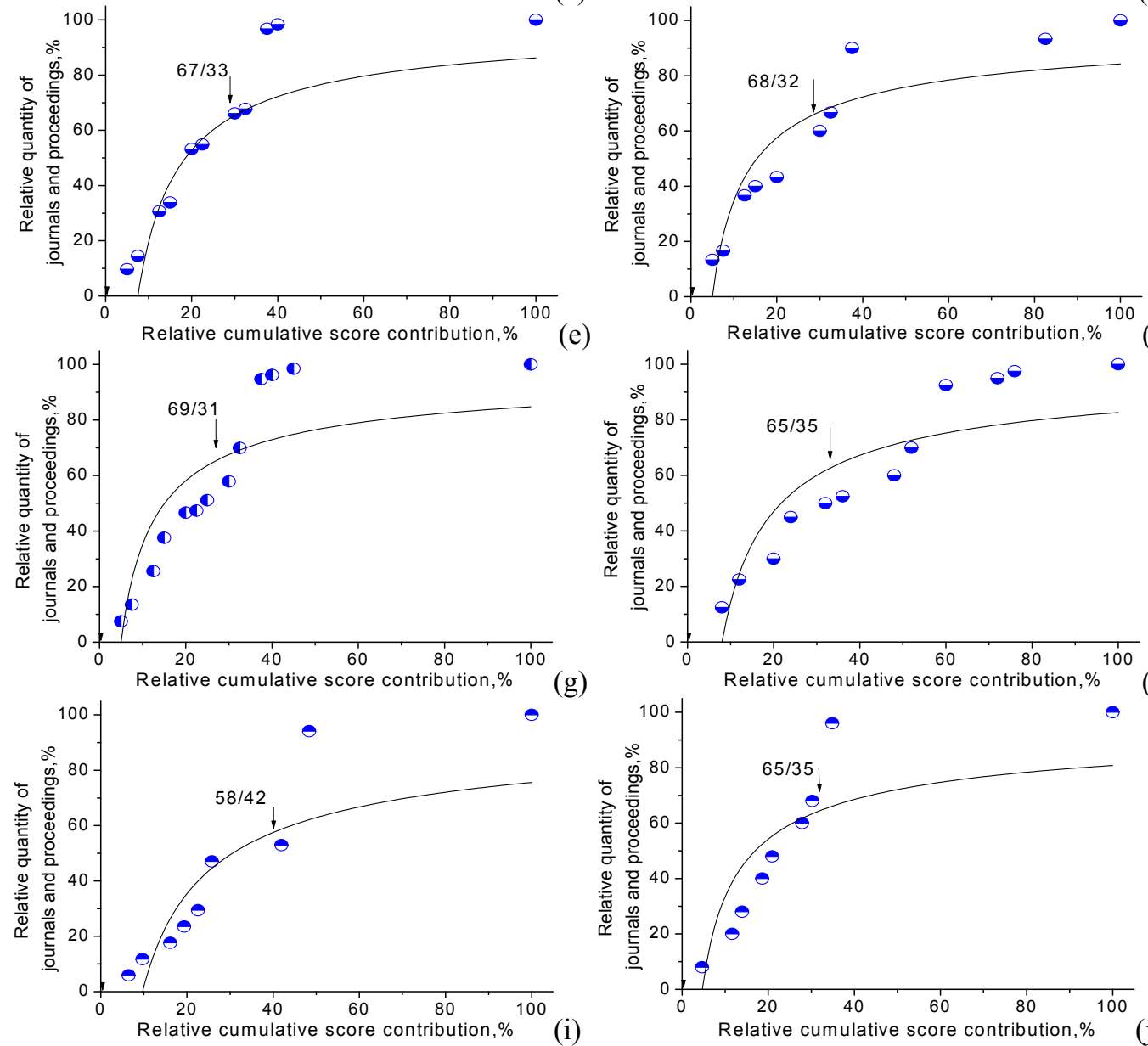

(g)

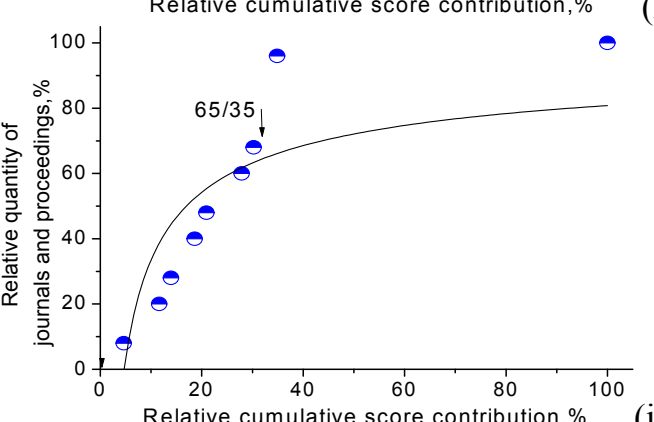

(h)

Fig. 4. Pareto cumulative distributions for the journals and proceedings referred to economy (a), history (b), pedagogy (c), politology (d), psychology (e), sociology (f), jurisprudence (g), state management (h), social communications (i), and physical training and sports science (j).

Ukr. J. Phys. Opt. 2018, Volume 19, Issue 2 
$22 \%$ of the relevant items corresponds to a single edition, "National Academy of Managerial Staff of Culture and Arts Herald" (the score 40). The relative fitting error in this case is equal to $20 \%$.

Our last subject is the journals and proceedings specialized in economy, history, pedagogy, politology, psychology, sociology, jurisprudence, state management, social communications, and physical training and sports science. The cumulative Pareto distributions for these editions are presented in Fig. 4.

For the journals and proceedings specialized in economy, the Pareto ratio is equal to $73 / 27$ (see Fig. 4a). Since the total number of editions in this branch is equal to 283 , here $27 \%$ correspond to 26 journals, of which minimal scores are higher than 15 . These editions belong to the categories B, C, D and E. 23 of these journals and proceedings have the scores equal or higher than 25. 163 editions are referred to the historical sciences. With the Pareto ratio $70 / 30$ for this group (see Fig. 4b), the number of items having the scores higher than 15 is equal to 4 . Only three editions from this group have the scores higher than 25. These are "Skhid" (the score 40), "Grani" (40) and "Bulletin Taras Shevchenko National University of Kyiv. Ukrainian studies" (25).

Among the journals and proceedings on pedagogy, 8 items are a result of the Pareto ratio equal to $73 / 27$ (see Fig. 4c). The minimal score for this group is higher than 15 . Nonetheless, only 4 editions have the scores equal to 25 or exceeding this value. These are "Proceedings of the National Aviation University" (the score 50), "Journal of Information Technologies in Education" (40), "Science Rise" (40) and "Medical Education" (30). The Pareto ratio is equal to 70/30 for the editions that are specialized in the politology (see Fig. 4d). The total number of journals and proceedings specialized in this branch is 53 . Hence, $30 \%$ of these journals and proceedings, i.e. 3 items, have the total scores higher than 15 . The relative fitting error in this case is equal to $24 \%$. There are only two editions with the scores higher than 25. These are "Grani" (the score 40) and "Odesa National University Herald. Sociology and Politics" (the score 33).As seen from Fig. 4e, the Pareto ratio for the journals and proceedings corresponding to psychology is equal to $67 / 33$. Only two editions among them have the scores higher than 15 . Here the relative error of fitting is equal to $24 \%$. The only edition from this branch, "Dnipropetrovsk University Bulletin. Series Psychology", has the score 40. The Pareto ratio for the journals and proceedings on sociology is equal to $68 / 32$ (see Fig. 4 f). Here $30 \%$ correspond to 3 items, with the fitting error $28 \%$. The minimal score for these items is higher than 15 .

As seen from Fig. 4g, the Pareto ratio for the juridical journals and proceedings is equal to $69 / 31$. Here 7 items correspond to $31 \%$ of these editions, with the fitting error $26 \%$. The two editions from this field have the scores higher than 25. These are "Medical Law" (40) and "Theory and Practice of Jurisprudence" (40). Among 40 editions concerned with the state management, only 3 items reveal the total scores higher than 15 . The Pareto ratio for this scientific field is $65 / 35$ (see Fig. $4 \mathrm{~h}$ ), with the fitting error $28 \%$. One of these journals, "Derzhavne upravlinnya: Udoskonalennya ta Rozvytok", has the score 25. Note also that only one of the journals belonging to the social communications, "Current Issues of Mass Communication", has a relatively high score, 43 , whereas the Pareto ratio for this field is equal to $58 / 42$ (see Fig. 4i), with the fitting error $38 \%$. Finally, the Pareto ratio for the journals and proceedings specialized in physical training and sports is equal to $65 / 35$ (see Fig. $4 \mathrm{j}$ ), with the fitting error $29 \%$. The score of only one edition, "Slobozhanskyi Herald of Science and Sports" (48), is higher than 15.

\section{Conclusions}

In the present work, we have analyzed the Ukrainian journals and proceedings specialized in the fields of humanitarian, social, juridical and economical sciences, using the approach to journal 
ranking developed earlier in [ Vasylkiv Yu. et al., 2017. Ukr. J. Phys. Opt. 18: 28-45]. Our analysis of the Ukrainian journals and proceedings is based on the Pareto distribution. We have found that, among the overall number of 1214 editions, 5 belong to the category B, 5 to the category C, 23 to the category D, and 24 to the category E. The categories F and G contain 1034 and 123 items, respectively. None of the Ukrainian editions has a prescribed impact factor, so that the highest category A is empty. Following from our analysis, one can see that the editions belonging to the categories B-E satisfy $81 \%$ of the minimal criteria. The total scores for these journals and proceedings are higher than 15 .

\section{References}

1. https://mon.gov.ua/storage/app/media/atestatsiya-kadriv-vyshchoikvalifikatisii/2018/01/24/naukovikh-fakhovikh-vidan-010118.doc

2. https://mon.gov.ua/storage/app/media/atestatsiya-kadriv-vyshchoikvalifikatisii/2018/01/24/elektronnikh-fakhovikh-vidan-010118.doc

3. González-Pereira B, Guerrero-Bote V P and Moya-Anegón F, 2010. A new approach to the metric of journals' scientific prestige: The SJR indicator. J. Informetrics. 4: 379-391.

Vasylkiv Yu., Mys O., Boyko V. and Vlokh R. 2018. Ukrainian scientific journals in the branches of juridical, economic, humanitarian and social sciences: a systematization. Ukr.J.Phys.Opt. 19: $80-91$.

Анотація. Проаналізовано стан справ з украӥнськими виданнями, що спеціалізуються в галузях гуманітарних, соиіальних, економічних $i$ юридичних наук. За критеріями, запропонованими нами, всі 1214 украӥнських журналів і збірників у згаданих галузях поділено на сім категорій. Виявлено, що найвища категорія А порожня, 5 видань належать до категорії B, 5 - до категорії $C, 23$ - для категорії D, 24-до категорії E i 1034 - до категорії F. Нарешті, найнижча категорія $G$ містить 123 видання. Одержані результати свідчать, що лише журнали і збірники, віднесені до категорій B-E, відповідають 81\% усіх необхідних критеріїв. Сумарні бали иих видань дорівнюють або вищі за 15.

Ukr. J. Phys. Opt. 2018, Volume 19, Issue 2 